\title{
Oral-based Bible translation: A contextualised model for the nomadic Himba people of southern Africa
}

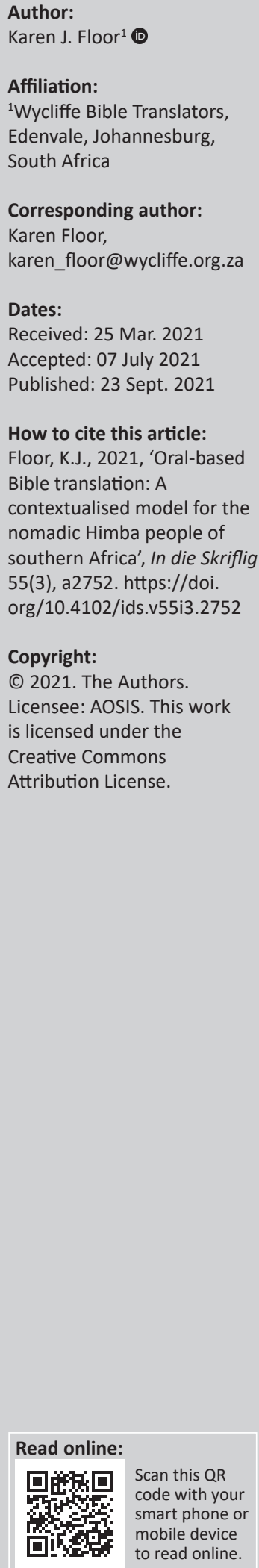

Historically, the work of Bible translation has involved multiple disciplines in a commitment to translate Scripture with integrity and faithfulness to the original Greek and Hebrew texts. Translating Scripture for primary oral societies has added another dimension to the need for accuracy, beauty and clarity in Scripture translation. It has been widely accepted in Western literate society that the Bible is accessed in written print in the form of a book. For oral-preference societies, such as the nomadic Himba and San peoples of southern Africa, a printed Bible has presented a challenge. Few people read or wish to read as their primary means of communication. In the case of the San family of languages, complex phonemic systems of up to 85 contrastive clicks have presented a challenge in developing 'readable' orthographies. This article has highlighted the rationale for oral-based Bible translation. The research aimed to address the translation needs of oral societies - some of whom are nomadic or semi-nomadic people groups. The recent missiological positioning of certain Bible translation practitioners has led to an oral-based approach to Bible translation which validates the cultural identity of modern oral communicators. Orally crafted translations of Scripture passages have been recorded and made available to oral societies through a range of media, including MP3 players, SD cards and mobile phone applications. The effectiveness of oral-based Bible translation among the Himba people has been seen in their response. What began as a three-year pilot project to explore the potential impact of oral-based Scripture among oral societies has led to a unanimous demand for a second three-year phase, and an expressed desire for a full oral-based Bible in the Himba language. The oral-based approach as described is currently used in nearly 20 other oral Bible translation, which reflects a felt need for oral-based Scripture among oral societies in southern Africa.

Contribution: Insights from the emerging practice of oral-based Bible translation in southern Africa provide valuable data for missiological approaches to communicating the gospel in the context of modern oral societies.

Keywords: oral-preference communication; nomadic societies; Bible translation; missiology; southern Africa; Himba and San peoples.

\section{Introduction}

\section{Background}

Translating the Bible is a complex task, involving multiple disciplines to maintain the integrity of the original Greek and Hebrew texts. Translators need to be grounded in the multi-faceted science of Bible translation, which incorporates expertise in 'anthropology, sociology, pragmatics, intercultural communication, orality studies, and literary studies' (Wendland 2012:1). Bible translation is also an art, seeking to employ aural features which are pleasing to the ear. The criteria for quality translation have been summarised by Wendland (2011) as the ' $A B C$ ' of standard practice, where $\mathrm{A}=$ accuracy to the original text; $\mathrm{B}=$ beauty in terms of euphonic artistry, aural features, ideophones, et cetera. The ultimate purpose of Bible translation, of course, lies in its clarity and ability to convey meaning. A good translation will open the window to let in the light of meaning as described in the original preface to the King James Bible (Maxey 2011).

\section{Objective}

Translating for oral societies adds another dimension to the challenges of Bible translation. Aiming for accuracy, beauty and clarity in a written translation is one thing. Achieving this in an oral translation is quite another, but try we must. 'A text's beauty is best experienced ... when a text is heard, not when it is read silently' (Maxey 2011:263). 
The most common way to access Scripture is still in printed book form. For the semi-nomadic oral societies, such as the Himba and San people groups of southern Africa, a printed Bible presents a real challenge. Few people read or wish to read as their primary means of communication. In the San family of languages, complex phonemic systems can have up to 85 contrastive clicks. This presents a challenge in developing 'readable' orthographies, let alone accessible Bible translations.

The San people form several minority groups, scattered in pockets across Angola, Botswana, Namibia and South Africa. The San have, for the most part, resisted the gospel. The Himba people of Namibia and Angola have also resisted the gospel. This semi-nomadic group is a strongly oral society that distinguishes itself from the neighbouring Herero. The oral identity of the San and Himba people groups provides a strong rationale for oral Bible translation.

Nearly two-thirds of the world's population are made up of oral-preference communicators. The San and Himba are among them. By oral preference we mean that learning, teaching and communication, in general, occur through oral medium, rather than through the medium of printed text. Historically, orality-literacy has been thought of as binary with one often viewed as superior or inferior to the other. This separates people into literate and illiterate groups. However, scholars concur that orality falls on a continuum. Lee (2005:2-40) outlines a spectrum of orality that covers five levels of preferred learning styles (Table 1): primary illiterate, functional illiterate, semi-literate, functional literate and highly literate. We conclude that orality is more of an indicator of media preference than literacy.

Among the five categories, the first three are classified as oral communicators in that they transmit information mainly through oral narrative. Literates, on the other hand, mostly use written text for teaching and learning information. The difference reveals a problem in presenting the gospel. Most Christian workers are highly literate communicators who work with oral communicators.

TABLE 1: A continuum of oral preference learning styles.

\begin{tabular}{|c|c|c|}
\hline Number & Variable & Description \\
\hline 1. & Primary illiterates & Those who cannot or will not read or write. \\
\hline 2. & Functional illiterates & $\begin{array}{l}\text { Those who know how to read and write. } \\
\text { However, these individuals learn mainly by } \\
\text { oral presentations and interactions. }\end{array}$ \\
\hline 3. & Semi-literates & $\begin{array}{l}\text { Those who studied as far as the tenth grade. } \\
\text { They waiver between the categories of oral } \\
\text { communication and functional literacy. } \\
\text { Nevertheless, semi-literates also learn better } \\
\text { by means of oral communication. }\end{array}$ \\
\hline 4. & Functional literates & $\begin{array}{l}\text { Those who have continued to develop their } \\
\text { ability to read and write up to and beyond } \\
\text { the tenth grade. These individuals are literate } \\
\text { learners. They easily understand and process } \\
\text { information and concepts transmitted in } \\
\text { written materials. }\end{array}$ \\
\hline 5. & Highly literate & $\begin{array}{l}\text { Those who regularly read and write at a very } \\
\text { advanced level. They have been raised in a } \\
\text { thoroughly word-based culture. They are } \\
\text { literate communicators who depend on } \\
\text { written material when recalling information. }\end{array}$ \\
\hline
\end{tabular}

Source: Lee, K.J., 2005, 'Bible storying: A recommended strategy for training church leaders in oral societies', PhD thesis, The Southern Baptist Theological Seminary, USA
This poses a problem in that oral and written literary genres differ in thought and verbal expression.

Several characteristics of oral thought and expression are identified by Ong (1982) in his seminal work on orality and literacy. He explains the different ways of managing knowledge and verbalisation in primarily oral cultures and cultures where the use of writing systems is deeply engrained. Some of these differences have particular relevance in the field of Bible translation, for example the characteristic of additive narrative. A clear example of this is found in the Creation narrative of Genesis 1 (from the 1610 Douay version, produced in a culture with residual oral characteristics):

In the beginning God created heaven and earth. And the earth was void and empty, and darkness was upon the face of the deep; and the spirit of God moved over the waters. And God said: 'Let there be light.' And light was made. And God saw that the light was good; and he divide the light from the darkness. And he called the light Day, and the darkness Night; and there was evening and morning one day. (vv. 1-5)

The New American Version renders the same account with subordinates ('when', 'then', 'thus', and 'while') which characterises analytical expressions typical of written narrative.

Other characteristics of oral-based expression include the use of 'clustering' - an idea with copious descriptions and parallel phrases as opposed to the more concise style of written text, which seeks to avoid redundancy. This style of oral narration enables listeners to track and back-loop in case they lose concentration while listening. If they miss the 'not only' phrase, they can tune into 'but also' without losing the gist of meaning (Ong 1982:39-40).

It is one thing to embrace the validity of oral literature. It is quite another to argue 'that humanity has come full circle in our communication method - from oral to written text to oral again' (Swarr, Gidoomal \& Araujo 2017:xix-xx). Oral communication forms are essential to modern-day audiovisual media, even among the educated. Professor Thomas Pettit (2012), of the University of Southern Denmark, refers to this as the 'Gutenberg Parenthesis'.

Gutenberg's printing press of the 15th century, revolutionised learning by making written text readily available. However, the technological revolution of the 21st century has turned the tide of access to knowledge. We have entered the age where technological literacy has superseded text-based literacy. Oral cultures may not be literate; they are leapfrogging text literacy for technological literacy, seen in their aptitude for modern devices: mobile phones, MP3 players, and the like.

The realisation that knowledge is no longer quantified by how literate a person is, but how able they are to 'take a quantum leap forward' (Swarr et al. 2017:xx), requires us to rethink our assumptions about Christian education, leadership development and Bible translation. 
TABLE 2: Phase 1 - Scripture passages selected for oral-based translation.

\begin{tabular}{|c|c|}
\hline Story title & Scripture reference \\
\hline 1. The Word of God & $\begin{array}{l}\text { John } 1 \text {; } 2 \text { Timothy } 3: 16 \text {; Hebrew } 4: 12 \text {; } \\
\text { Revelation } 12 \text {; other passages to } \\
\text { explain the bigger picture. }\end{array}$ \\
\hline 2. Who is God? & $\begin{array}{l}\text { Introductory material included to set } \\
\text { the stage for listening to story sets. }\end{array}$ \\
\hline 3. The main story of the Bible (Timeline) & $\begin{array}{l}\text { Introductory material included to set } \\
\text { the stage for listening to story sets. }\end{array}$ \\
\hline 4. God creates the Heaven and the earth & Genesis 1-2 \\
\hline $\begin{array}{l}\text { 5. The creation of people, and the garden } \\
\text { of Eden }\end{array}$ & Genesis 1 - 2 \\
\hline 6. God creates the spirit beings & Genesis 2; 3 \\
\hline $\begin{array}{l}\text { 7. People's rejection of God's love, and the } \\
\text { consequence of that }\end{array}$ & Genesis 3 \\
\hline 8. God promises a solution & Genesis 3 \\
\hline 9. Cain and Abel & Genesis 4 \\
\hline 10. Noah and the Flood & Genesis 6 \\
\hline 11. Tower of Babel & Genesis 11 \\
\hline 12. Abraham & Genesis 12 \\
\hline 13. Sodom and Gomorrah & Genesis 14 \\
\hline 14. Isaac & Genesis. 22 \\
\hline 15. Esau and Jacob & Genesis 35:1-14 \\
\hline 16. Joseph & Genesis 41 \\
\hline 17. Moses & Exodus 2 and other options \\
\hline 18. Plagues in Egypt and the Passover & Passover and overview to plagues \\
\hline 19. God rescues the Israelites from slavery & Exodus $12: 31 ; 13: 17-22$ \\
\hline 20. God's provision in the desert & Exodus $16 ; 17$ \\
\hline $\begin{array}{l}\text { 21. Preparations for giving the ten } \\
\text { commandments to Israel }\end{array}$ & Exodus $19-20$ \\
\hline $\begin{array}{l}\text { 22. God gives the ten commandments to } \\
\text { Israel and the tabernacle }\end{array}$ & Exodus 20 \\
\hline $\begin{array}{l}\text { 23. Israel's unfaithfulness; God's judgement } \\
\text { and salvation ( } 40 \text { years) }\end{array}$ & Exodus 32 \\
\hline 24. Israel and the promised land & Numbers 22:22-35 \\
\hline 25. Judges and kings & $1 \& 2$ Samuel \\
\hline 26. God's prophets for Israel & Isaiah 53; \\
\hline $\begin{array}{l}\text { 27. The births of John the baptist; the birth } \\
\text { of Jesus }\end{array}$ & Matthew 1:18 \\
\hline 28 Jesus' baptism & Matthew 3:1-17 \\
\hline 29. Jesus resists Satan & Matthew 4 \\
\hline 30. Jesus begins His ministry & Matthew 5:1-12 \\
\hline 31. You have to be born again & John 3 \\
\hline 32. The election of the 12 disciples & Matthew 4:18; \\
\hline $\begin{array}{l}\text { 33. Jesus' love revealed: healing, calming } \\
\text { the storm, feeding, inviting people and } \\
\text { forgiving sins }\end{array}$ & Mark 9:14-27 \\
\hline 33a Jesus healing & Matthew4:23-25 \\
\hline $33 \mathrm{~b}$ Jesus inviting and seeking the lost & Luke 15 \\
\hline $33 \mathrm{c}$ Jesus forgiving sins & Mark 2:1-12 \\
\hline $33 \mathrm{~d}$. Jesus raises Lazarus from the dead & John 11 \\
\hline 33e. Jesus calms the storm & Matthew 8:23-27 \\
\hline $33 \mathrm{f}$. Feeding of the 5000 & John 6:1-14 \\
\hline \multicolumn{2}{|l|}{ 34. Jesus' teachings } \\
\hline 34a. Hell or Heaven? & Luke 16:19-31 \\
\hline $\begin{array}{l}\text { 34b The way of the pharisees versus God's } \\
\text { way }\end{array}$ & Matthew 7 \\
\hline $34 \mathrm{c}$. Jesus is the only way to eternal life & Luke 9:28-36 \\
\hline $\begin{array}{l}\text { 34d. Jesus blesses the children; Jesus teaches } \\
\text { the rich young man }\end{array}$ & Mark 10:13-16 \\
\hline $34 \mathrm{e}$. Jesus teaches us how to pray & Matthew 6:5-15 \\
\hline 34f. It is unwise to trust in riches & Matthew 6:25-34 \\
\hline $\begin{array}{l}\text { 35. Jesus is the Christ, the Son of God; Jesus } \\
\text { is glorified }\end{array}$ & Luke 9:28-36 \\
\hline $\begin{array}{l}\text { 36. Jesus enters Jerusalem; Judas plans to } \\
\text { betray Jesus; Jesus establishes the } \\
\text { communion meal }\end{array}$ & Matthew 21:1-11 \\
\hline 37. Jesus captured & Matthew 26 - Matt28 \\
\hline 38. Jesus is crucified and buried & Matthew 27:32-44 \\
\hline
\end{tabular}

TABLE 2 (Continues...): Phase 1 - Scripture passages selected for oral-based translation.

\begin{tabular}{|c|c|}
\hline Story title & Scripture reference \\
\hline $\begin{array}{l}\text { 39. The meaning of Jesus death from the } \\
\text { perspective of the Old Testament }\end{array}$ & Luke 22 \\
\hline $\begin{array}{l}\text { 40. Jesus' resurrection; appearance to His } \\
\text { disciples; ascension }\end{array}$ & Luke 24 \\
\hline 41. The coming of the Holy Spirit & Matthew 28:16-20 \\
\hline \multirow{2}{*}{$\begin{array}{l}\text { 42. Heading Home (our thankful response to } \\
\text { God's love) }\end{array}$} & Psalm 23 \\
\hline & $\begin{array}{l}\text { Revelation 21:1-8; } 22 \text { (the garden } \\
\text { again) }\end{array}$ \\
\hline \multirow[t]{6}{*}{ 43. The cost of following Jesus } & John 16:7-15 \\
\hline & Psalm 1 \\
\hline & Jeremiah 17:5-18 \\
\hline & Luke 10 \\
\hline & John 13 \\
\hline & 2 Timothy 3:10-13 \\
\hline
\end{tabular}

Source: Compiled by the translation committee of the San Bible Partnership, comprised of participating Bible Translation organisations

\section{Missiological positioning of oral Bible translation in Christian ministry among oral societies}

From his work as a practitioner of Christian ministry to the nomadic Himba people of Namibia, Petersen (2011:11) highlights the experience that nomadic communities were, for Christian missions, difficult to reach. He asks what it would take for nomads to receive the gospel and be discipled. 'Would [they] first need to learn to read and write?' In the context of mission, he asserts that oral people should not be expected to change. Rather, it is the missionaries who need to change their understanding that oral people communicate and assimilate knowledge differently.

'The word for illiteracy in Indonesia is buta hurfuf, meaning blind to letters' (Lee 2005:20). One could argue that 'letter blindness' has hindered the Christian practitioner's communication to the oral person in a literate world. Peterson (2011) concludes that it may not be the nomads who have resisted the Christian message, but the packaging of the Christian message, using written text that did not speak to a 'letter-blind people'.

To quote Bosch (1991):

nomads are a 'pilgrim people' journeying with God. This is fundamental to the missiological framework suited to nomads. A key component of this missiological framework for nomads, is what Christopher Wright (2006) refers to as the process of 'unlocking the Bible's grand narrative. (pp. 373-374)

Bringing the rich oral tradition of oral societies together with the grand narrative that runs through Scripture, allows the story of redemption to naturally unfold from Creation to the second coming of Christ.

The term storying acknowledges the communication potential of recounting Scripture in story form. Lee (2005:60) cites Terry's creation (1990) of the term storying and his reasons for coining the term:

It was felt that a new term was needed to better describe the narrative method that was emerging for telling the Bible as story 
... there was a desire to make a distinction between storytelling of all kinds of stories in the village setting as opposed to communicating God's Word in the familiar and highly accepted oral culture format. 'Storying' in chronological Bible storying was coined to express this method. (pp. 16-169)

Storying is at the heart of the performance of Scripture, 'understood ... as a sincere embodiment of communication' (Maxey 2009:2). For the Himba people, storytelling illustrates what Avery (1996:13-14) calls 'heart music.' In the case of the Himba, the objective of touching their hearts with the gospel message is not as simple as speaking Otjihimba in preference to Otjiherero (a neighbouring dialect that includes written communication in their literary heritage.) The fact that the Himba language is only spoken, not written - and the fact that there is essentially no desire to see that change - is integral to their cultural identity. To use Maxey's metaphor of language 'fluency' (2009:268), any missionary ministry among the Himba would need to attain high levels of fluency in the oral culture of the people. Ignoring their oral identity would be to offer them the gospel as notes of music on a page without allowing them to hear the melody that is intended to move the heart.

In a paper, presented at the 2018 Orality Conference in Richmond, Virginia, Floor (2018) asserted that oral-based Bible translation has recently emerged as a valid methodology. This contextualised approach to Bible translation for oral societies presents an alternative to written translations and oral Bible storying. Bible translation practitioners are still debating the authoritative nature of oral-based Scripture. The printed product of Bible translation is still the norm among the majority of practitioners. Most practitioners validate the oral communication preference of oral societies. The debate centres around the authority of orally crafted Scripture. Ironically, the original Hebrew and Greek texts were orally communicated, and within the written tests we have today are many oral cues. The notion of limiting scriptural authority to written text is an assumption of modern New Testament studies that "'early Christianity" was a literate culture'. It was 'oral communication and oral recitation of texts, not the reading and writing of texts, prevailed in the early centuries during which the Gospel of Mark gained authority among communities of Christians' (Horsley 2010).

\section{A contextualised approach to Bible translation for the oral nomadic Himba society}

At least 18 active translation projects fall into the category of Oral Bible Translation in southern Africa. The first, and probably ground-breaking example, explains Floor (2018), is the Himba oral translation on the Namibia and Angola border. What is unique about the Himba translation, is the availability of a full Bible in the Herero language - a closely related dialect. Intelligibility between the two variants is high (over 90\%), and a revision of the 1920 Herero translation is in progress. Nevertheless, in conversations with Himba community leaders, it became clear that, although they accept the printed Herero Bible as authoritative, there is a felt need for a translation that takes into consideration the distinct identity of the Himba nomadic and oral culture. The Herero, in contrast, are sedentary and literate. The point is that, linguistically speaking, the Herero and Himba languages are similar. Geographically and culturally, however, Himba and Herero societies are far removed from one another.

In 2015, it was decided that translation would need to be orally drafted and, after being checked for faithfulness to the original biblical text, produced as MP3 files for the Himba pastoralists to carry with them on audio devices. Modern Himba women maintain their strong traditional identity with their ochre-wrapped locks, leather clothing and copper bracelets. At the same time, they can be seen carrying cell phones on their waistbands or listening to music from earphones attached to their MP3 players.

A contextualised oral translation method, referred to by Floor (2018) as 'the Himba Approach' because of its application among the Himba people, has developed to make Scripture more accessible to this nomadic oral society. The approach has quite unintentionally gained widespread acceptance and spread to other areas where oral Bible translation is a felt need.

The weekly schedule underlying the 'Himba approach' has come to consist of the following, for example:

- On Mondays, the four local translators discuss the biblical narrative to be translated that week. Discussion takes place between the translators, the exegetical coach and a local pastor who has theological training. The story is read aloud from the new Herero revision, as well as from available English versions, and is then discussed in depth.

- On Tuesdays, the story is read out loud again in Herero by one of the translators (all four oral translators are also literate). The reading is repeated several times, while the other three translators attempt a first draft of the narrative. After a few attempts, a recording is made by plugging a good microphone into a laptop, using the Audacity software. After internalising the story, the translators catch a ride that afternoon to one of two outlying Himba villages, not too far from Opuwo, where the translation is being done. In one of the two villages they hope to meet up with the master storyteller involved in this project. Once they locate him, the recordings are played to him and he then orally recounts the text, making stylistic changes. Faithfulness to the original biblical text is checked by the local exegetical advisor. Periodically (and sometimes during the story crafting sessions), a quality assurance consultant will connect with the team remotely through technology to check the uploaded recording of a drafted translation. The reworked recording is then presented to the local villagers that evening. Incorporating the feedback from local reviewers, the translators attempt a new recording in the village - sometimes that very evening or otherwise the next morning. Before sunrise, the story is performed once more. 
- On Wednesday mornings, the translators return to Opuwo to rest.

- On Thursdays, the translators prepare and conduct the final recording.

- Fridays are reserved for recording an oral back translation of the translated passage of the week. Depending on the internet connection, which is often less than desirable, the two audio files (the final Thursday recording, and accompanying recording of the back translation into English) are sent via Dropbox to the translation consultant who checks the translated passage for exegetical soundness and consistency of key terms - the same way he would check for faithfulness to the original text of a written translation. The consultant visits the project three times a year.

\section{Assessing the effectiveness of oral- based translation}

All completed drafts of the oral-based Himba translations have been checked, revised, locally recorded and widely distributed on SD cards and MP3 players. Reports from the field confirm that the cattle herders carry devices around their necks or waists, enabling them to follow their herds in remote areas, listening to Scripture as they go.

In setting translation goals for the first three-year phase:

- An initial story set that provides a chronological panorama of the Bible - 40 Bible narratives.

- A second story set that addresses specific issues in the community - 20 Bible narratives.

- The Nativity narrative from Luke.

- The book of Mark.

Production in the first phase exceeded the goal of 60 translated oral passages. The translation committee agreed to use the remaining time allocation to complete an additional 23 stories from Genesis, bringing the total up to 83 oral stories plus the book of Mark in a period of three years.

A second phase was launched in January 2019 with the goal of completing the book of Genesis. Given the overwhelmingly positive impact, the translation team, in discussion with the Pastors Forum and other stakeholders, have agreed to continue translating the whole Bible in oral form. For phase two, however, the goal is to complete Genesis, and to translate Romans and Hebrews.

The above description represents six years of developing an oral-based Bible translation. All the critical components of a sound Bible translation process are followed - from the initial exegesis to final approval for publication and distribution. The difference is that, while written manuscripts result in a book, oral-based translation is directed towards oral communities who will access the translation, mainly through the oral medium of MP3 devices with the option of publishing transcriptions of the oral translations:

- Exegesis: local exegetical facilitators (trained in theology) guide discussion with the translators to understand the meaning of a Bible passage before translating. This eliminates the need for adapting an expatriate's exegesis to local worldview.

- Drafting translation: local exegetical facilitators (trained in theology) guide discussion with the translators to understand the meaning of a Bible passage before translating.

- Community review: an initial draft of the oral translation is tested and reviewed by local community members to ensure that the translation is understandable, conveys the intended meaning, and is accepted as being authentic to the target language.

- Back translation: a word-for-word back translation of the oral draft is done into the source language of wider communication (e.g. English or Portuguese) to enable the consultant to evaluate decisions made about key terms and other matters of biblical faithfulness to the original text.

- Consultant check: the translated draft recording, together with a back translation, is sent to a quality assurance consultant who has extensive knowledge of scriptural exegesis and the original languages to ensure faithfulness to the original text of the translation.

- Approval: consultant checked translations are approved for oral and/or written publication and distribution.

\section{Early successes and lessons learned}

In 2018, a celebration of the first Otjihimba Scriptures took place in Opuwo, Namibia. A modest, but meaningful milestone event was held to mark the completion of the first three-year phase of oral-based Bible translation into Otjihimba. The stadium was packed with Himba men, women and children. What made this event so significant, was that the Himba community of seminomadic pastoralists turned out in full force, marking this historical moment of the first public reading of Scripture in Otjihimba. In just three years since the start of this translation project, the community was celebrating the completed translation of the book of Mark, plus a total of 83 biblical passages from both theOld and New Testament. The atmosphere was electric. This was not the usual Christian gathering, attended by Herero, carrying their printed Bibles. This was clearly an event that drew the interest of Himba people, sensitive to their historically marginalised status in Namibian society.

To mark this historic occasion, several Scripture-based songs were composed in Otjihimba. A six-year-old boy stood up to recite from the oral version. His performance of the Creation story in Genesis 1 showed the memorable and performable nature of the oral Himba translation. Many testimonies were shared of how the translated Bible stories were impacting the lives of the Himba community. The Opuwo Pastors Forum has expressed the need for the whole Bible in oral format for the Himba. They agree that this is meeting a real need, bringing the gospel to the Himba in a packaging that is suited to their oral nomadic culture and lifestyle.

Another success is the suitability of the distribution medium for the oral translations. Petersen (2011) affirms that:

in Namibia the radio is a well-used instrument among nomads. This is not foreign, nor does it need to be imported. Other media can then compliment this one. These can include cassettes, compact discs or MP3 players. The MP3 players would work best as the others can easily be destroyed by the dust, sun, rain and so forth. (p. 97) 
One of the advantages of 'publishing' the oral translations on MP3 devices is that the lifestyle of nomads does not lend itself to attending regular meetings. Their dependence on the elements means that they cannot commit to arriving for set gathering at set times or designated places. The nomad finds it easier to carry a device that contains the orally translated passages that can be listened to at leisure. Petersen (2011) explains that:

an oral document can be carried into the mountains. It can also be carried without much fuss for its weight. In a nomadic setting an oral Bible will serve two purposes: first, it helps the people hear and second, it makes God's word mobile as they travel. (pp. 149-150)

The nomadic lifestyle of the Himba presents an ongoing challenge for Bible translation in that they have no fixed abode. Very few Himba live in town. Their habitat is determined by the needs of their herds. Their way of life does not include schedules and deadlines. This may cause the project to be delayed, due to Himba storying crafters not being available as often as needed.

Another real challenge is the age of some of the Himba translators. Some are very young, which is an advantage in terms of technological aptitude. However, given that only older men are 'the movers and shakers of nomadic society, youth cannot serve as a catalyst for transformation' (Petersen 2011:22). Fortunately, the translation team is currently balanced by male seniority, but this cultural phenomenon is something to be aware of.

A particular area that merits further reflection is the selection of translated passages. In the first phase of the Himba translation, several stories were selected. Many of these fell into the category of essential component in presenting the gospel. However, I think there is room for developing (and perhaps guiding) the selection process further. From the outset, that is, from the first phase of oral-based Bible translation, there is a need to provide a story set that presents oral communities with the whole plan of redemption - from Creation to the coming of Christ through to his second coming.

\section{Conclusion}

There is no doubt that primary oral communities respond more readily to the gospel message when they can access it in a medium suited to their oral preference for expressing image, thought and knowledge. The recent emergence of an oral-based Bible translation, unintentionally coined as 'the Himba approach' has seen some early successes, which point to the potential for wider acceptance of the Christian message than ever before in the history of Christian ministry among the Himba and other oral societies in southern Africa. At the same time, the demands of the multi-disciplinary process of Bible translation are augmented by the extra dimension of challenges attributed to the nomadic lifestyle of the Himba pastoralists. Further research and reflection on the effect of the Himba approach is needed to refine the practice of oral-based Bible translation elsewhere, but it is in practising that performance is perfected; thus, the efforts of early practitioners of the 'Himba approach' are to be encouraged as a valuable contribution to the work of Bible translation among oral societies.

\section{Acknowledgements Competing interests}

The author has declared that no competing interest exists.

\section{Author's contributions}

I declare that I am the sole author of this research article.

\section{Ethical considerations}

This article followed all ethical standards for a research without direct contact with human or animal subjects.

\section{Funding information}

This research received no specific grant from any funding agency in the public, commercial, or not-for-profit sectors.

\section{Data availability}

Data sharing is not applicable to this article as no new data were created or analysed in this study.

\section{Disclaimer}

The views and opinions expressed in this article are those of the author and do not necessarily reflect the official policy of any affiliated agency of the author.

\section{References}

Avery, T., 1996, 'Music of the heart: The power of indigenous worship in reaching unreached peoples with the gospel', Mission Frontiers 18, 13-14.

Bosch, D.J., 1991, Transforming mission: Paradigm shifts in theology of mission, Maryknoll, New York, NY.

Floor, S.J., 2018, 'A reflective overview of Oral Bible Translation in Southern Africa, with special focus on the need for an oral translation brief', paper presented at the The OBT Conference, Richmond, VA, 12-14 March.

Horsley, R.A., 2010, 'Oral and written aspects of the emergence of the Gospel of Mark as Scripture', Oral Tradition 25(1), 101.

Lee, K.J., 2005, 'Bible storying: A recommended strategy or training church leaders in oral societies', PhD thesis, The Southern Baptist Theological Seminary, USA.

Maxey, J.A., 2009, From orality to orality: A new paradigm for contextual translation of the Bible, Cascade Books, Eugene, OR.

Maxey, J.A., 2011, 'Bible translation and performance for the parish: The enduring beauty of the King James Version', Word \& World 31(3), 263-270.

Ong, W.J., 1982, Orality and literacy: The technologizing of the word, Routledge, London.

Petersen, G.P., 2011, 'Ministry to nomads: A comprehensive missiological approach', $\mathrm{PhD}$ thesis, University of the Free State, RSA.

Pettitt, T., 2012, 'Bracketing the Gutenberg parenthesis', Explorations in media ecology 11(2), 95-114

Swarr, D., Gidoomal, R. \& Araujo, P., 2017, Master Storyteller: God's oral communication in the Bible and Hebrew tradition, The Centre for Oral Scriptures in conjunction with The Lausanne Movement, Richmond, VA.

Terry, J.O., 1997, 'Chronological Bible storying to tribal and nomadic peoples', International Journal of Frontier Missions, 14(4), 168-169.

Wendland, E., 2011, 'Life-style s translating: A workbook for Bible translators', SIL International Publications in Translation and Text linguistics 5, xv-263.

Wendland, E. \& Noss, P., 2012, 'Bible translation', in The Encyclopedia of Applied Linguistics, Blackwell Publishing, NY.

Wright, C.J.H., 2006, The mission of God: Unlocking the Bible's grand narrative, Nottingham, UK: Intervarsity Press. 